\title{
Workshop ON Writing OF Scientific Journal Articles For Teachers OF SMA Negeri 1 Palangka Raya
}

\section{Workshop Penulisan Artikel Jurnal llmiah Untuk Guru SMA Negeri 1 Palangka Raya}

\author{
Yossita Wisman ${ }^{1)}$, Bernisa $^{2)}$, Karelius $^{3)}$, Muhammad Rifky ${ }^{4)}$, Siswo $^{5)}$ \\ ${ }^{1)}$ Dosen Program Studi Manajemen Pendidikan, FKIP Universitas Palangka Raya \\ ${ }^{2)}$ Dosen Program Studi Pendidikan Olah Raga, FKIP Universitas Palangka Raya \\ ${ }^{3)}$ Dosen Program Studi Kimia, FMIPA Universitas Palangka Raya \\ ${ }^{4)}$ Mahasiswa Program Studi Pendidikan Olah Raga, FKIP Universitas Palangka Raya \\ ${ }^{5)}$ Mahasiswa Program Studi Kimia, FMIPA Universitas Palangka Raya \\ e-mail: yossita@fkip.upr.ac.id
}

\begin{abstract}
Nowadays, in order to obtain promotion from the rank of Group IVa to IVb, a teacher is required to provide scientific works. However, according to Ministerial Decree No. 16/2009, scientific work has become a promotion requirement from Group IIIb to IIIc; thus, the teacher must have the ability to produce scientific papers. This community service was aimed to provide knowledge and skills for teachers of SMAN 1 Palangka Raya to produce and publish scientific papers in the ISSN local journals. Participants in the activity generally consisted of junior teachers and by using training methods in the form of lectures and questions and answers, demonstrations and practice.
\end{abstract}

Keywords: Workshop, scientific articles, SMAN 1 Palangka Raya

\begin{abstract}
ABSTRAK
Guru saat ini jika mau kenaikan pangkat harus melampirkan karya ilmiahnya bagi Golongan IV a ke IVb namun dalam Keputusan Menteri N0.16 tahun 2009 karya tulis ilmiah sudah menjadi syarat kenaikan dari Golongan IIIb ke IIIc, maka guru harus mempunyai kemampuan untuk membuat karya tulis ilmiah. Program Kemitraan Masyarakat Stimulus (PKMS) ini bertujuan untuk memberikan pengetahuan dan keterampilan bagi guru-guru SMA Negeri 1 Palangka Raya khususnya mereka yang mengikuti pelatihan penulisan artikel jurnal ilmiah, dimana nantinya artikel ilmiah yang dihasilkan dalam bentuk artikel diharapkan dipublikasikan di jurnal ber ISSN. Peserta kegiatan umumnya terdiri dari guru-guru yunior yang disesuaikan dengan Peraturan Menteri Pendayagunaan Aparatur Negara dan Reformasi Birokrasi No. 16 Tahun 2009 Tentang Jabatan Fungsional Guru dan Angka Kreditnya yang antara lain mengubah kenaikan pangkat dan golongan guru untuk naik golongan dari IVa harus membuat karya tulis ilmiah sekarang harus dari golongan IIIb ke IIIc. Metode pelatihan menggunakan ceramah dan tanya jawab, demonstrasi dan praktek.
\end{abstract}

Kata kunci: Workshop, Artikel Jurnal IImiah, Siswa SMA Negeri 1 Palangka Raya

\section{PENDAHULUAN}

Misi bangsa Indonesia antara lain menetapkan bahwa sistem dan iklim pendidikan nasional yang demokratis dan bermutu guna memperteguh akhlak mulia, kreatif, inovatif, berwawasan kebangsaan, cerdas, sehat, berdisiplin dan bertanggungjawab, berteknologi dalam rangka mengembangkan kualitas manusia Indonesia.

Pengembangan profesi guru adalah kegiatan guru dalam rangka pengamalan ilmu pengetahuan, teknologi dan ketrampilan utuk peningkatan mutu baik bagi bagi proses belajar belajar mengajar dan profesionalisme tenaga kependidikan lainnya maupun dalam rangka menghasilkan sesuatu yang bermanfaat bagi pendidikan dan kebudayaan. Adapun kegiatan pengembangan profesi yang dimaksud adalah 1) membuat karya tulis/karya ilmiah di bidang pendidikan,
2) menemukan teknologi dibidang pendidikan, 3) membuat alat pelajaran/alat peraga atau alat bimbingan, 4) menciptakan karya tulis ilmiah, dan mengikuti kegiatan pengembangan kurikulum (Depdiknas, 2001: 1-2). Maka menulis karya ilmiah merupakan syarat mutlak bagi guru yang akan naik pangkat dan golongan tertentu.

Karya tulis ilmiah sering disebut juga karangan ilmiah, karya ilmiah dan tulisan ilmiah. Penyebutan yang berbeda-beda menunjukkan pada satu karya yang sama yaitu tulisan ilmiah, yang berbeda dengan tulisan ilmiah. Brotowidjono (1985: 8-9) mengatakan bahwa "karangan ilmiah adalah karangan ilmu pengetahuan yang menyajikan fakta dan ditulis menurut metodologi penulisan yang baik dan benar". Wibowo (2001:61) mengatakan bahwa" suatu karangan dapat dikatakan ilmiah jika ia mengungkapkan suatu permasalahan 
dengan ilmiah". Maryadi dalam Harun, dkk(2001:14) mendefinikan karya ilmiah yaitu "suatu karya yang memuat dan mengkaji permasalahan tertentu dengan menggunakan kaidah-kaidah keilmuan". Berdasarkan ketiga definisi tersebut dapat disimpulkan bahwa karya tulis ilmiah adalah suatu tulisan atau karangan yang menyajikan dan membahas suatu topok keilmuan tertentu secara ilmiah.

Segala macam tulisan atau karangan dalam bidang ilmu tertentu, teoritis (murni) ataupun praktis (terapan), yang disusun secara sistematis berdasarkan fakta-fakta obyektif dan atau hasil penalaran logis, dapat dikategorikan sebagai karya tulis ilmiah. Karakteristik karya tulis ilmiah menurut Soeparno(1997:51) adalah sebagai berikut:

a. Masalah diungkapkan dan dipecahkan secara secara ilmiah

b. Mengungkapkan pendapat berdasarkan fakta agar tidak terjerumus kedalam subyektifitas

c. Bersifat tepat, lengkap, dan benar. Itu sebabnya sebelum menulis, kita mesti meneliti tepattidaknya masalah yang akan dikemukakan, baik dari segi permasalahannya maupun bidang ilmiahnya.

d. Bagian-bagian tulisan dikembangkan secara runtut, sistematis, dan logis agar tulisan yang dihasilkan membentuk kesatuan (kohesif) dan kepaduan (koheren).

e. Bersifat tidak memihak (obyektif). Aspek pribadi atau emosional sebaiknya ditinggalkan, karena akan membuat tulisan kita diwarnai prasangka atau kepentingan pribadi sehingga kadar keilmiahannya menjadi pudar.

Guru saat ini jika mau kenaikan pangkat harus melampirkan karya ilmiahnya bagi Golongan IVa ke IVb namun dalam Keputusan Menteri N0.16 tahun 2009 karya tulis ilmiah sudah menjadi syarat kenaikan dari Golongan IIIb ke IIlc, maka ke depan guru harus mempunyai kemampuan untuk membuat karya tulis ilmiah. Pelaksanaan Kegiatan Program Pengabdian kepada Masyarakat (PPM) melibatkan Guru-guru sebagai mitra yang akan mengikuti penelitian penulisan karya ilmiah, dengan tujuan guru-guru menjadi terbiasa dan memiliki pengetahuan, keterampilan dalam menulis karya ilmiah dalam bentuk artikel yang akan dipublikasikan dalam jurnal nasional ber ISSN.

Sekolah yang dijadikan mitra oleh pengusul selama pelaksanaan program PPM adalah SMA Negeri 1 Palangka Raya. Visi sekolah adalah menjadi institusi pendidikan penghasil sumberdaya manusia yang Pancasilais, bermutu dalam ilmu pengetahuan dan teknologi, iman serta karakter. Visi tersebut dijabarkan ke dalam program peningkatan kualitas dan kuantitas pendidikan, baik terhadap guru dan siswa melalui berbagai pendidikan formal dan informal. Termasuk peningkatan sarana dan prasarana gedung sekolah. Dalam peningkatan kualitas pendidikan, yang pertama dilakukan adalah dimulai dari guru-guru dengan terus meningkatkan jenjang pendidikan ke taraf yang lebih tinggi. Kemudian, kegiatan peningkatan pendidikan melalui berbagai penelitian, seminar, penyuluhan dan lainnya (Anonim, 2019).

Pada umumnya guru-guru SMA Negeri 1 Palangka Raya masih banyak yang kesulitan naik pangkat dan golongan IVa/Pembina ke IVb/Pembina Tingkat I ke atas yang kendalanya adalah pembuatan karya tulis ilmiah yang disyaratkan harus dipenuhi angka kredit minimal 12 dari unsur pengembangan profesi yang antara lain meliputi melakukan kegiatan karya tulis/karya ilmiah dalam bidang pendidikan. Nampak bahwa para guru enggan menulis karya tulis ilmiah karena kurang pengetahuan dan kemampuan tentang pembuatan karya tulis ilmiah.

Berdasarkan analisis situasi dan kajian pustaka di atas, dapat disimpulkan bahwa para guru SMA Negeri 1 Palangka Raya masih mengalami permasalahan dalam membuat karya tulis ilmiah terutama dalam bentuk artikel ilmiah. Permasalahan tersebut disebabkan oleh berbagai faktor, dua diantaranya yang sangat penting adalah kemauan dan kemampuan menulis guru yang masih memerlukan pembinaan.

Berdasarkan uraian di atas, dipertimbangkan perlu dilakukan kegiatan penelitian penulisan karya ilmiah bagi para guru, yang karena keterbatasan waktu, tenaga dan pengetahuan serta kemampuan guru-guru, dibatasi para guru SMA Negeri 1 Palangka Raya. Penelitian difokuskan pada peningkatan kemauan dan kemampuan (motivasi) guru menulis karya tulis ilmiah berjenis artikel ilmiah yang akan diterbitkan dalam bentuk jurnal nasional ber ISSN. Harapannya melalui kegiatan penelitian ini guru-guru menjadi produktif dalam menghasilkan karya tulis ilmiah.

\section{METODE PELAKSANAAN PENGABDIAN}

\section{Persoalan Prioritas dan Penanganannya}

Guru-guru di SMA Negeri 1 Palangka Raya masih mengalami permasalahan dalam membuat karya tulis ilmiah dalam jenis apapun. Permasalahan tersebut disebabkan oleh berbagai faktor, dua diantaranya yang sangat penting adalah kemauan dan kemampuan menulis guru yang masih memerlukan pembinaan.

Mengacu pada permasalahan yang diajukan, maka penanganan untuk menyelesaikan permasalahan yang dihadapi mitra adalah dengan melaksanakan penelitian penulisan artikel ilmiah dengan memberikan informasi dan arahan dalam hal :

1. Teknik menyusun kerangka tulisan karya ilmiah

2. Teknik mengumpulkan bahan-bahan tulisan, mengorganisasikan, dan mengonsep karya tulis ilmiah.

3. Teknik menulis dan menyunting karya ilmiah

4. Penelusuran referensi melalui berbagai sumber

5. Penulisan artikel ilmiah dengan pendampingan dan supervisi dari tim pengabdian masyarakat, 
yang nantinya diharapkan dapat dipublikasikan dalam jurnal nasional ber ISSN.

\section{Metode Pendekatan Sebagai Solusi}

Metode penelitian yang digunakan untuk mendukung keberhasilan program antara lain sebagai berikut:

1. Ceramah dan Tanya Jawab

Metode ini dipilih untuk menjelaskan tentang materi yang bersifat teoritik terkait dengan aturan perundangan yang menyangkaut kenaikan pangkat menurut Peraturan Menteri Pendayagunaan Aparatur Negara dan Reformasi Birokrasi No.16 Tahun 2006 Tentang Jabatan Fungsional Guru dan Angka Kreditnya yang mewajibkan kenaikan golongan dari IIlb ke Illc harus mengumpulkan angka kredit minimal 4. Pada hal sebelumnya hanya mereka yang mau kenaikan golongan IVa ke golongan IVb saja.

2. Demonstrasi

Metode ini digunakan untuk menjelaskan suatu proses kerja secara bertahap sehingga dapat memberi kemudahan bagi peserta dapat mengamati secara cermat proses pembuatan karya tulis ilmiah dari persiapan sampai jadi artikel ilmiah.

3. Latihan / Praktek atau tutorial

Pada metode ini peserta mempraktekkan pembuatan karya tulis ilmiah dengan bimbingan pelatih sehingga peserta dapat membuat karya tulis ilmiah dengan baik yang diharapkan dapat diterbitkan dalam jurnal nasional ber ISSN.

\section{Partisipasi Mitra dalam Pelaksanaan Program}

Partisipasi Mitra dalam hal ini SMA Negeri 1 Palangka Raya dalam pelaksanaan Program Pengabdian kepada Masyarakat (PPM) ini adalah memfasilitasi Pengusul dalam hal mengarahkan guru-guru SMA Negeri 1 Palangka Raya sebagai peserta penelitian penulisan karya ilmiah untuk guru yang dilatih oleh Pengusul. Selain itu Mitra juga menyediakan sarana dan prasarana yang mendukung program Pelatihan ini.

\section{Luaran yang dihasilkan}

Adapun luaran yang ditargetkan dari program PPUPIK “Kependidikan", sesuai dengan komponen rencana inovasi "Kependidikan" adalah dokumen kegiatan berupa metode penelitian yang sudah disusun untuk memudahkan para guru SMA Negeri 1 Palangka Raya untuk menghasilkan karya ilmiah dalam bentuk artikel. Dokumen kegiatan lain yang diperoleh dari kegiatan ini adalah artikel-artikel ilmiah guru-guru SMA Negeri 1 Palangka Raya, yang diharapkan dapat diterbitkan dalam jurnal lokal ber ISSN.

\section{HASIL DAN PEMBAHASAN}

A. Pelaksanaan kegiatan

\section{Langkah-Langkah Kegiatan PPM}

BALANGA: Jurnal Pendidikan Teknologi dan Kejuruan ISSN 2338-426X
Untuk melaksanakan PPM ini dibutuhkan waktu selama 3 bulan mulai sejak penandatanganan kontrak kerja dilaksanakan sampai dengan penyerahan laporan akhir kegiatan. Berbagai bentuk kegiatan yang dilaksanakan PPM ini adalah sebagai berikut:

a. Persiapan kegiatan yang dilaksanakan oleh TIM pengabdi untuk merencanakan kegiatan yang mencakup waktu, materi dan teknis pelaksanaan kegiatan.

b. Konfirmasi dengan Kepala Sekolah SMA Negeri 1 Palangka Raya

c. Konfirmasi dilaksanakan di Sekolah SMA Negeri 1 Palangka Raya. Acara membicarakan waktu pelaksanaan, pelaksanaan, tempat, sarana prasarana dan pembiayaan serta peserta.

b. Pelaksanaan Pembukaan oleh Kepala Sekolah SMA Negeri 1 Palangka Raya dan dihadiri oleh semua anggota TIM pengabdian dari Universitas Palangka Raya.

c. Dilaksanakan tanggal 16 Nopember 2019 dari pukul 08.00 sampai pukul 15.00 WIB di Sekolah SMA NEGERI 1 Palangka Raya dengan acara pelatihan penulisan karya tulis ilmiah dan tutorial dengan peserta pelatihan didampingi TIM pengabdian.

d. Tanggal 27 Nopember 2019 pelaksanaan tutorial dalam pembuatan karya tulis ilmiah yang meliputi makalah, diktat dan laporan PTK serta diakhiri dengan penutupan.

\section{Faktor Penghambat dan Pendukung}

Faktor Penghambat:

Peserta telah dipilih yang masih senior dan tidak semuanya PNS tetapi masih ada yang honorer. Sedang yang PNS masih ada yang golongan II sehingga belum merasa perlu pembuatan karya tulis ilmiah itu karena baru dipandang perlu jika sudah golongan IIIb.

Faktor Pendukung:

a. Gedung SMA Negeri 1 Palangka Raya dekat jalan raya sehingga tranportasi mendukung gedungnya cukup untuk pelaksanaan pelatihan.

b. Gedung SMA Negeri 1 terletak dikota Palangka Raya dan sangat dekat dengan Universitas Palangka Raya sebagai tempat bertugas narasumber.

c. Materi diperlukan oleh mayoritas guru untuk kenaikan pangkat dan sertifikasi.

\section{Materi Pelatihan (Terlampir)}

Materi pelatihan ini disesuaikan dengan tingkat pemahaman dasar dan tujuan pelatihan itu sendiri, karena pelatihan ini di tujukan untuk mempersiapkan guru-guru dalam penulisan Karya Ilmiah, maka materi di sesuaikan dengan tujuan pelatihan tersebut. Secara umum materi di bagi atas peningkatan pemahaman di bidang :

1. Teknik menyusun kerangka tulisan karya ilmiah 
2. Teknik mengumpulkan bahan-bahan tulisan, mengorganisasikan, dan mengonsep karya tulis ilmiah.

3. Teknik menulis dan menyunting karya ilmiah

4. Penelusuran referensi melalui berbagai sumber

5. Penulisan artikel ilmiah dengan pendampingan dan supervisi dari tim pengabdian masyarakat, yang nantinya diharapkan dapat dipublikasikan dalam jurnal nasional ber ISSN.

\section{Waktu pelaksanaan}

Waktu Pelaksanaan kegiatan pengabdian pada masyarakat secara umum dilaksanakan pada waktu kegiatan sekolah :

Tanggal : 16 Nopember 2019

Tempat : SMA NEGERI 1 Palangka Raya

\section{Jadwal Pelaksanaan}

Jadwal pelatihan penulisan karya ilmiah guruguru SMA NEGERI 1 Palangka Raya oleh Yossita Wisman, SE, M.MPd

\section{Perserta}

Pelaksanaan Kegiatan Program Pengabdian kepada Masyarakat (PPM) melibatkan Guru-guru sebagai mitra yang akan mengikuti penelitian penulisan karya ilmiah, dengan tujuan guru-guru menjadi terbiasa dan memiliki pengetahuan, keterampilan dalam menulis karya ilmiah dalam bentuk artikel yang akan dipublikasikan dalam jurnal nasional ber ISSN. Peserta pelatihan ditujukan untuk guru-guru dengan Golongan IVa ke IVb namun mengingat bahwa dalam Keputusan Menteri N0.16 tahun 2009 karya tulis ilmiah sudah menjadi syarat kenaikan dari Golongan IIIb ke IIlc, maka peserta pelatihan juga melibatkan guru-guru Golongan IIIb ke IIIc.

\section{Alat Bantu (tools)}

Alat bantu utama dalam pelatihan ini adalah satu unit laptop dan LCD Proyektor, hard copy materi dari narasumber, white board dan spidol serta alat tulis. Guru-guru juga diminta menyiapkan laptop dan modem untuk keperluan pelatihan dan praktik mandiri.

\section{Metode Pelatihan}

Metode penelitian yang digunakan untuk mendukung keberhasilan program antara lain sebagai berikut:

\section{Ceramah dan Tanya Jawab}

Metode ini dipilih untuk menjelaskan tentang materi yang bersifat teoritik terkait dengan aturan perundangan yang menyangkaut kenaikan pangkat menurut Peraturan Menteri Pendayagunaan Aparatur Negara dan Reformasi Birokrasi No.16 Tahun 2006 Tentang Jabatan Fungsional Guru dan Angka Kreditnya yang mewajibkan kenaikan golongan dari III B ke III C harus mengumpulkan angka kredit minimal 4 . Pada hal sebelumnya hanya mereka yang mau kenaikan golongan IV a ke golongan IV b saja.

\section{Demonstrasi}

Metode ini digunakan untuk menjelaskan suatu proses kerja secara bertahap sehingga dapat memberi kemudahan bagi peserta dapat mengamati secara cermat proses pembuatan karya tulis ilmiah dari persiapan sampai jadi artikel ilmiah.

3. Latihan / Praktek atau tutorial

Pada metode ini peserta mempraktekkan pembuatan karya tulis ilmiah dengan bimbingan pelatih sehingga peserta dapat membuat karya tulis ilmiah dengan baik yang diharapkan dapat diterbitkan dalam jurnal nasional ber ISSN.

\section{Hasil Pelaksanaan Kegiatan PPM}

Hasil pelaksanaan kegiatan PPM dirasakan oleh TIM pengabdian maupun peserta pelatihan sangat memuaskan. Dengan indikator kedatangan peserta dalam setiap pertemuan, dan mengikuti pelatihan dengan antusias. Hasil pelatihan diantara 15 peserta berasal dari berbagai disiplin ilmu (mata pelajaran). Berdasarkan hasil diskusi dan penyebaran serta pengisian angket, sebagian besar guru-guru di SMA Negeri 1 Palangka Raya hanya terbatas mengetahui tentang artikel jurnal ilmiah dan belum pernah menulis di artikel jurnal ilmiah. Para guru berpendapat bahwa kegiatan ini sangat bermanfaat bagi mereka dan sangat berkeinginan setelah kegiatan pelatihan mereka memiliki keterampilan menulis artikel jural ilmiah, dan tulisan mereka dapat dipublikasikan minimal di jurnal lokal atau nasional ber- ISSN. Berikut adalah beberapa dokumentasi pelaksanaan pelatihan dapat dilihat pada Gambar 1, Gambar 2 dan Gambar 3 di bawah ini.

Tabel 1 Materi Workshop

\begin{tabular}{clc}
\hline No & \multicolumn{1}{c}{ Materi } & Durasi \\
\hline & Sabtu, 16 Nopember 2019 & 2 Jam (Teori) \\
\hline 1 & Teknik menulis dan menyunting Artikel Jurnal Ilmiah & 3 Jam (Praktek) \\
\hline 2 & Tutorial dan Pendampingan. & 1 jam (Praktek) \\
& $\begin{array}{l}\text { Penulisan Artikel Jurnal Ilmiah dengan pendampingan dan supervisi } \\
\text { dari tim pengabdian masyarakat, yang nantinya diharapkan dapat } \\
\text { dipublikasikan dalam jurnal nasional ber ISSN. }\end{array}$ & \\
\hline
\end{tabular}


Tabel 2 Jadwal Workshop

\begin{tabular}{|c|c|c|c|c|}
\hline No & Waktu Pelaksanaan & Acara & Pelaksana & Keterangan \\
\hline \multirow[t]{2}{*}{1} & 16 Nopember 2019 & \multirow[t]{2}{*}{$\begin{array}{l}\text { Registrasi dan } \\
\text { Pendaftaran }\end{array}$} & \multirow[t]{2}{*}{ Panitia } & \multirow[t]{2}{*}{$\begin{array}{l}\text { Tim Pengabdian } \\
\text { Masyarakat }\end{array}$} \\
\hline & $08.00-08.30$ WIB & & & \\
\hline \multirow{2}{*}{2} & 16 Nopember 2019 & \multirow{2}{*}{$\begin{array}{l}\text { Pemaparan } \\
\text { Materi }\end{array}$} & \multirow{2}{*}{$\begin{array}{c}\text { Yossita Wisman, SE., } \\
\text { M.Mpd }\end{array}$} & \multirow{2}{*}{ Narasumber } \\
\hline & $08.30-10.30$ WIB & & & \\
\hline \multirow{2}{*}{3} & 16 Nopember 2019 & \multirow{2}{*}{ Break } & \multirow{2}{*}{ Panitia } & \multirow{2}{*}{$\begin{array}{c}\text { Tim Pengabdian } \\
\text { Masyarakat }\end{array}$} \\
\hline & $10.30-11.00$ WIB & & & \\
\hline \multirow[t]{2}{*}{4} & 16 Nopember 2019 & \multirow{2}{*}{$\begin{array}{c}\text { Tutorial dan } \\
\text { Pendampingan } \\
\text { Penyusunan } \\
\text { Artikel I }\end{array}$} & \multirow{2}{*}{$\begin{array}{c}\text { Yossita Wisman, SE., } \\
\text { M.Mpd }\end{array}$} & \multirow{2}{*}{ Narasumber } \\
\hline & $11.00-12.30$ WIB & & & \\
\hline \multirow[t]{2}{*}{5} & 16 Nopember 2019 & \multirow[t]{2}{*}{ ISHOMA } & \multirow[t]{2}{*}{ Panitia } & \multirow[t]{2}{*}{$\begin{array}{c}\text { Tim Pengabdian } \\
\text { Masyarakat }\end{array}$} \\
\hline & $12.30-13.30$ WIB & & & \\
\hline \multirow[t]{2}{*}{6} & 16 Nopember 2019 & \multirow{2}{*}{$\begin{array}{c}\text { Tutorial dan } \\
\text { Pendampingan } \\
\text { Penyusunan } \\
\text { Artikel II }\end{array}$} & \multirow[t]{2}{*}{$\begin{array}{l}\text { Yossita Wisman, SE., } \\
\text { M.Mpd }\end{array}$} & \multirow[t]{2}{*}{ Narasumber } \\
\hline & $13.30-15.00$ WIB & & & \\
\hline \multirow[t]{2}{*}{7} & 16 Nopember 2019 & \multirow[t]{2}{*}{$\begin{array}{c}\text { Penyempurnaan } \\
\text { Artikel }\end{array}$} & \multirow[t]{2}{*}{ Panitia } & \multirow[t]{2}{*}{$\begin{array}{c}\text { Tim Pengabdian } \\
\text { Masyarakat }\end{array}$} \\
\hline & $15.00-16.00$ WIB & & & \\
\hline
\end{tabular}

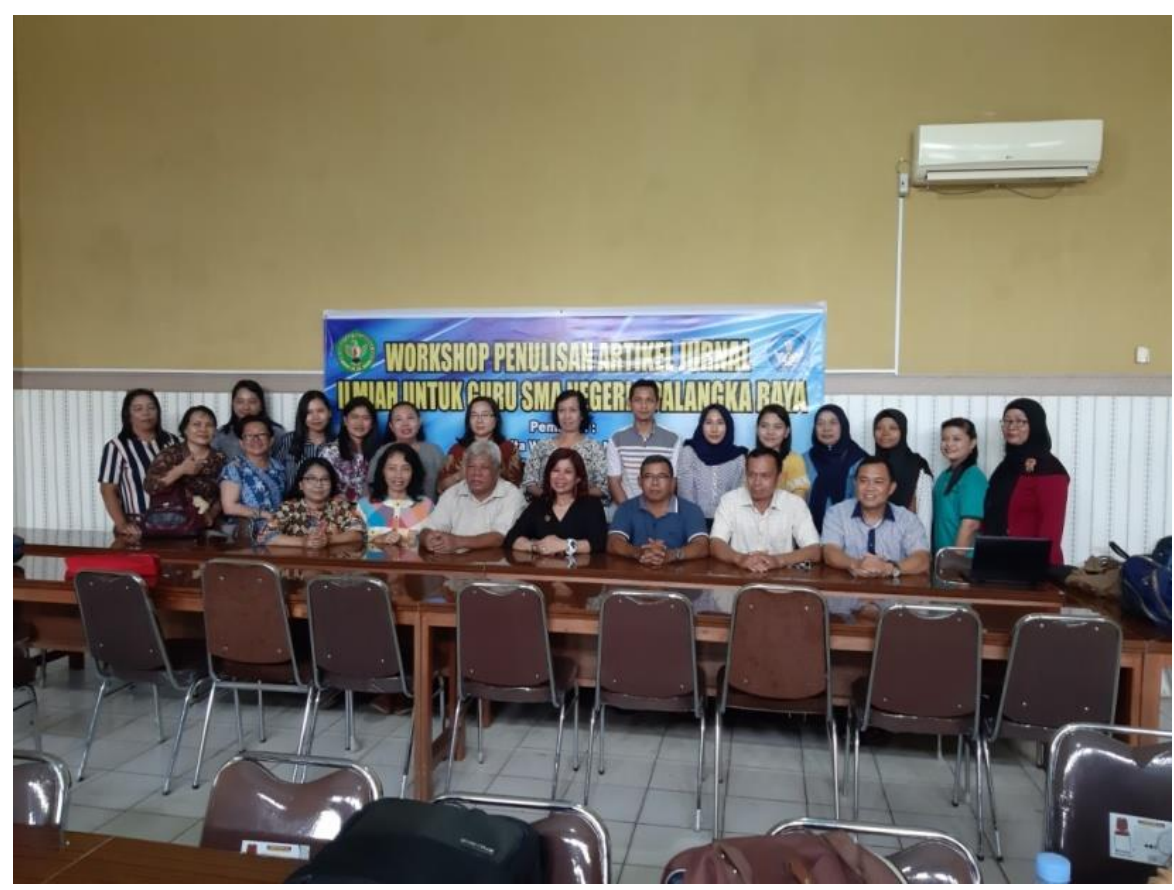

Gambar 1. Materi Pelatihan Penulisan Artikel Jurnal Ilmiah dengan Pemateri Yossita Wisman, SE, M.MPd 


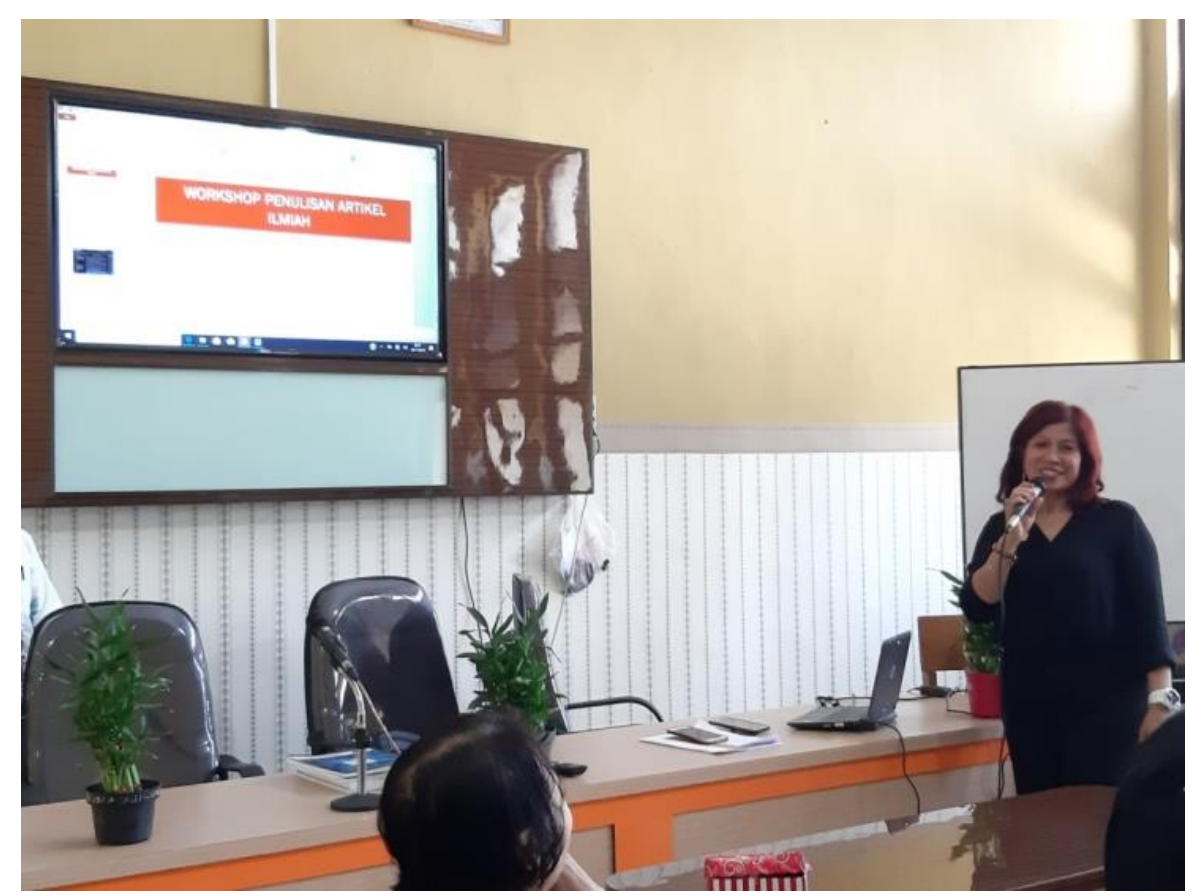

Gambar 2. Pelatihan Penulisan Artikel Jurnal Ilmiah untuk Guru SMA Negeri 1 Palangka Raya

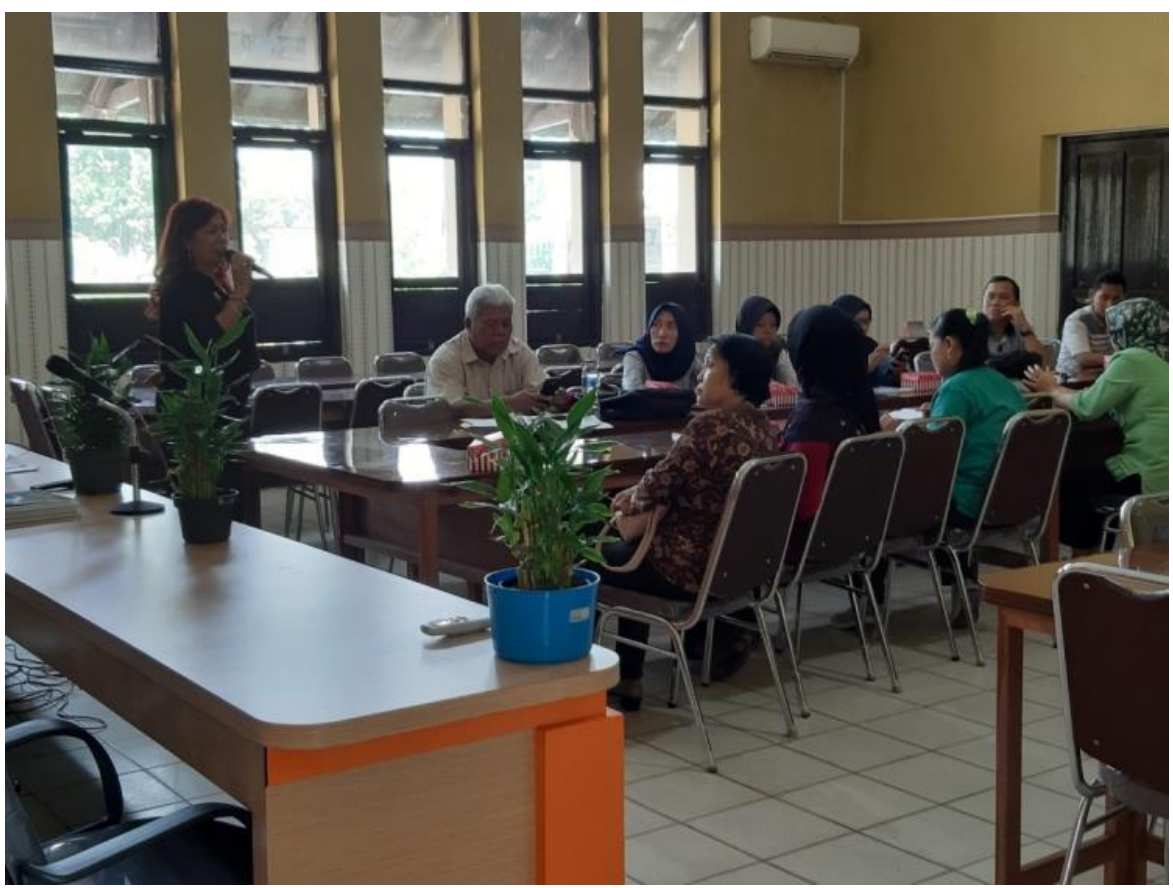

Gambar 3. Pemateri memaparkan Materi kepada Guru SMA Negeri 1 Palangka Raya Bertanya

\section{Pembahasan Hasil Pelaksanaan Kegiatan PPM}

Sebagian besar materi yang direncanakan dalam proposal dijalankan. Namun berdasarkan hasil konfirmasi dengan guru Sekolah SMA Negeri 1 dan berbagai pertimbangan sedikit agak berubah dari perencanaan. Karena ternyata dari sebagian guru sudah ada yang bertindak sebagai penilai angka kredit kenaikan pangkat untuk guru beranggapan bahwa nilai BALANGA: Jurnal Pendidikan Teknologi dan Kejuruan ISSN 2338-426X angka kredit untuk artikel yang dipublikasikan di jurnal ilmiah nasional ber-ISSN tidak lebih besar jika dibandingakn dengan laporan PTK. Hal ini sangat disayangkan mengingat semula guru-guru sudah sangat antusias untuk mengikuti kegiatan pelatihan ini, sehingga pemateri perlu memotivasi kembali guru-guru bahwa meskipun nilai angka kredit artikel jurnal ilmiah tidak lebih besar dibandingkan laporan PTK, tetapi 
untuk satu laporan PTK guru-guru dapat menghasilkan lebih sari 1 artikel untuk jurnal ilmiah, sehingga jika diakumulasikan nilainya tetap akan lebih besar. Selain itu untuk menulis sebuah artikel tidak harus diawali dari laporan PTK tetapi dari data-data saat guru mengajar sehari-haripun bisa digunakan. Motivasi ini ternyata berhasil kembali membuat guru-guru SMA
Negeri 1 Palangka Raya kembali bersemangat mengikuti pelatihan penulisan artikel jurnal ilmiah. Selain kegiatan pemaparan materi dan diskusi, juga disebarkan angket untuk di isi guru-guru terkait tentang kegiatan pelatihan ini. Berikut hasil dari angket yang disebarkan :

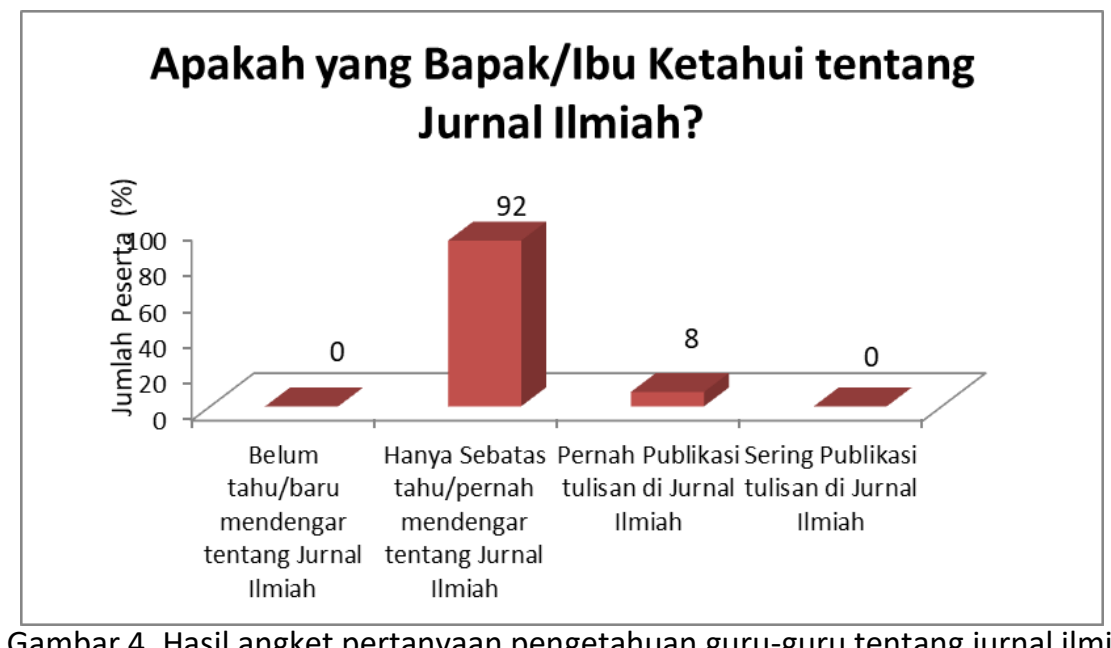

Gambar 4. Hasil angket pertanyaan pengetahuan guru-guru tentang jurnal ilmiah

Pertanyaan pertama terkait pengetahuan guru-guru tentang jurnal ilmiah. Sebanyak 92\% guruguru peserta pelatihan hanya sebatas pernah mendengar tentang jurnal ilmiah, dan $8 \%$ peserta pelatihan pernah publikasi tulisan di jurnal ilmiah. Hasil ini bukan suatu hal yang mengherankan karena selama ini guru-guru lebih terbiasa dengan laporan Penelitian Tindakan Kelas (PTK) yang dijadikan syarat KTI untuk kenaikan pangkat terutama untuk guru-guru di bawah golongan 4, sehingga mereka sangat jarang bahwa tidak pernah $(0 \%)$ mengetahui tentang jurnal ilmiah. Selain itu komunitas guru berbeda dengan perguruan tinggi yang lebih menekankan bentuk KTI yang dipublikasikan dalam bentuk artikel jurnal ilmiah baik nasional maupun internasional. Demikian halnya dalam distribusi perhitungan angka kredit untuk kenaikan pangkat, guru-guru hanya membutuhkan angka kredit yang kecil pada bidang KTI dibandingkan dosen yang mensyaratkan 35\% dari total angka kredit kenaikan pangkat adalah bidang penelitian.

Pertanyaan pertama pada angket yang sebarkan menjadi berhubungan dengan pertanyaan kedua tentang pengalaman guru-guru peserta pelatihan dalam menulis artikel yang diterbirkan di jurnal ilmiah (Gambar 5). Sebanyak 92\% peserta pelatihan belum pernah menulis artikel jurnal ilmiah dan sebanyak $8 \%$ sudah menulis dan artikelnya diterbitkan dijurnal ilmiah.

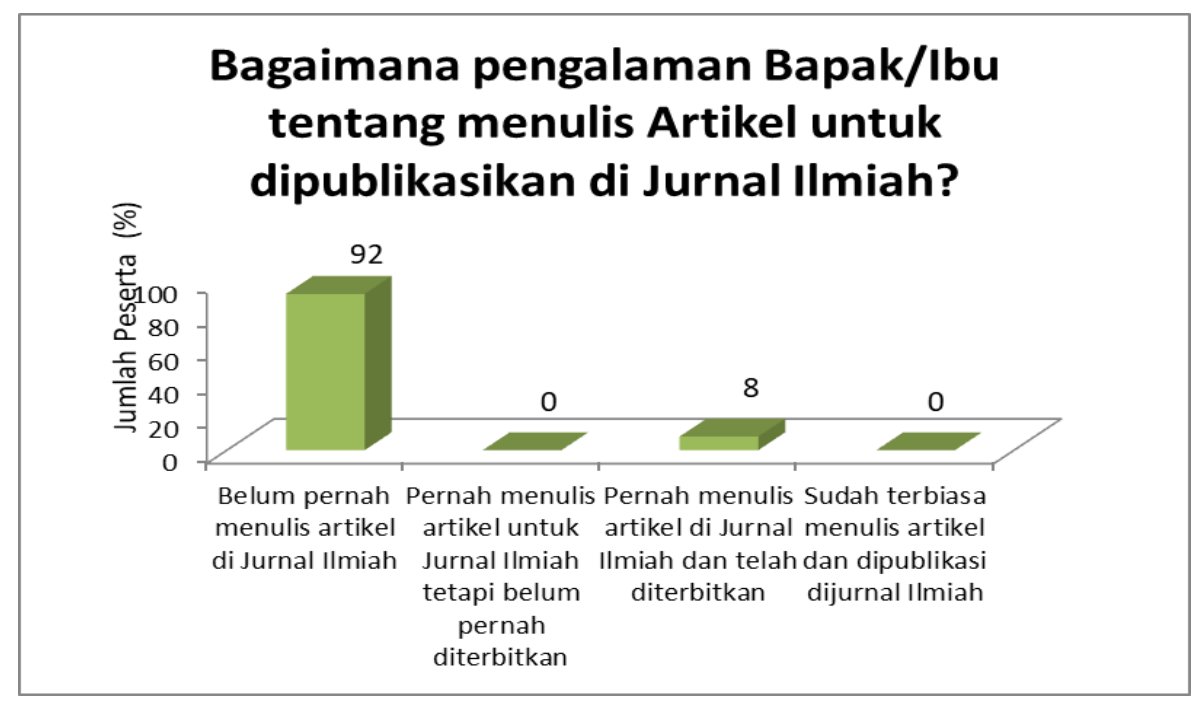

Gambar 5. Hasil angket pertanyaan tentang pengalaman guru-guru menulis artikel ilmiah 


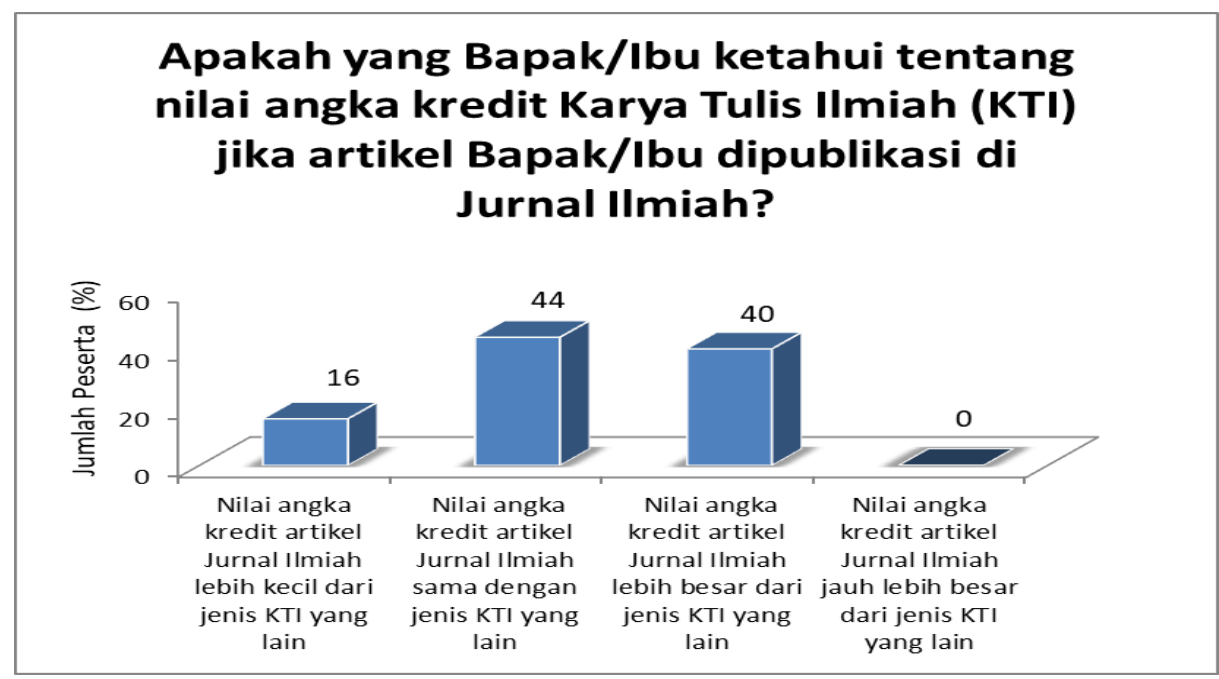

Gambar 6. Hasil angket nilai angka kredit artikel yang dipublikasi di jurnal ilmiah

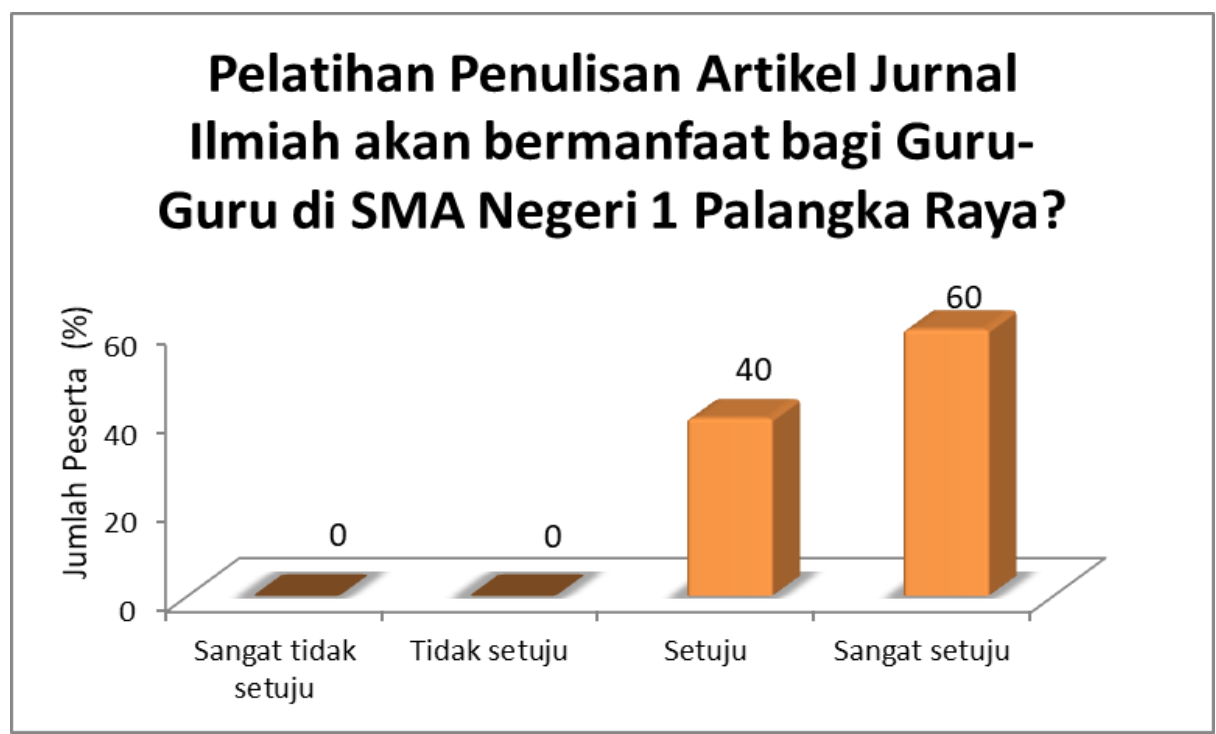

Gambar 7. Hasil angket manfaat pelatihan penulisan artikel jurnal ilmiah

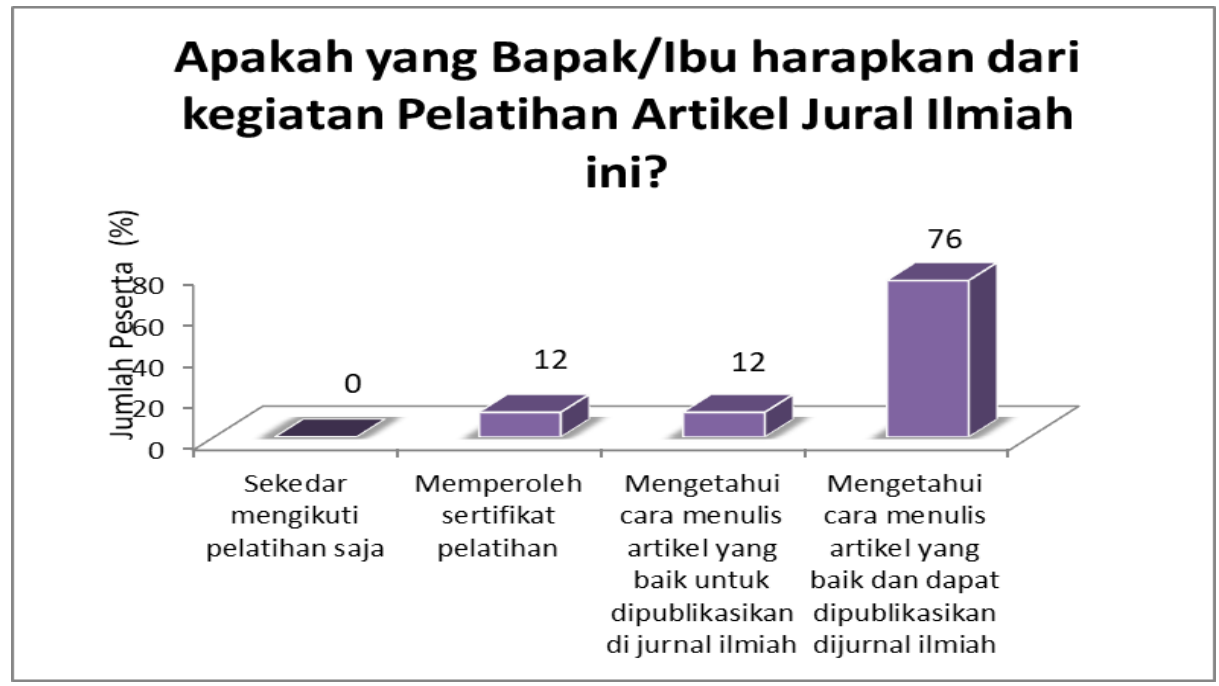

Gambar 8. Hasil angket harapan peserta setelah pelatihan penulisan artikel jurnal 
Berdasarkan Gambar 5, materi yang diberikan narasumber dikembangkan tidak hanya sebatas penjelasan tentang sistematika penulisan artikel jurnal, tetapi juga menekankan bagaimana teknis terkait proses-proses yang harus dilalui peserta sehingga artikelnya dapat diterbitkan di jurnal. Hal ini mengingat bahwa guru-guru peserta pelatihan ternyata tidak mengetahui bahwa proses penerbitan tulisan (artikel) dalam jurnal ilmiah, dimulai dari memasukkan tulisan, dilanjutkan proses review dan pernyataan artikel diterima sampai artikel tersebut diterbitkan dalam jurnal ilmiah.

Terkait dengan nilai angka kredit dari artikel ilmiah yang diterbitkan dalam jurnal ilmiah (Gambar 6). Jawaban dari guru-guru peserta seminar menjadi beragam. Sebagian besar menyatakan bahwa sebanyak $16 \%$ peserta pelatihan menyatakan nilai angka kredit artikel dalam jurnal ilmiah lebih kecil dari jenis KTI yang lain. Nilai angka kredit artikel dalam jurnal ilmiah sama dengan jenis KTI yang lain sebanyak (44\%) dan sebanyak $40 \%$ menyatakan bahwa nilai angka kredit artikel dalam jurnal ilmiah lebih besar dari jenis KTI yang lain. Hal ini menunjukkan bahwa pengetahuan guru-guru peserta pelatihan tentang perhitungan angka kredit, terutama bidang KTI masih minim. Hal ini wajar terjadi karena seperti sudah dijelaskan sebelumnya guru-guru lebih terbiasa dengan laporan PTK daripada artikel jurnal, sehingga melalui pelatihan ini diharapkan guru-guru menjadi lebih terbiasa untuk menghasilkan produk KTI mereka tidak hanya dalam bentuk laporan penelitian PTK tetapi juga artikel jurnal ilmiah.

Berdasarkan Peraturan Menteri Pendidikan Nasional No. 35 Tahun 2010 tentang Petunjuk Teknis Pelaksaan Jabatan Fungsional Guru dan Angka Kreditnya, bahwa nilai angka kredit artikel jurnal ilmiah nasional maksimal 3 kredit, sedangkan laporan PTK apabila hanya dalam bentuk laporan saja tidak diakui angka kreditnya, kecuali dipublikasikan dan di simpan diperpustakaan. Hal ini menunjukkan bahwa akan lebih menguntungkan bagi guru-guru untuk menulis artikel yang dipublikasikan di jurnal ilmiah daripada hanya sekedar membuat PTK.

Gambar 7 dan 8 menunjukkan tentang pendapat peserta pelatihan tentang manfaat pelatihan dan harapan peserta pelatihan setelah mengikuti pelatihan penulisan artikel jurnal ilmiah. Masing-masing sebesar $76 \%$ peserta pelatihan menyatakan bahwa pelatihan in sangat bermanfaat bagi mereka dan berharap mereka mengetahui cara menulis artikel yang baik dan tulisan mereka dapat dipublikasikan di jurnal ilmiah. Hal ini menunjukkan antusias yang besar dari peserta pelatihan terhadap penulisan artikel jurnal, dan harapan mereka agar tulisannya dapat dipublikasikan di jurnal ilmiah, untuk itu narasumber akan memberikan kesempatan pembimbingan/pendampingan di luar waktu pelatihan bagi guru-guru peserta pelatihan yang ingin tulisannya diterbitkan di jurnal ilmiah, sehingga diharapkan dari pelatihan ini akan dihasilkan output artikel guru-guru yang dipublikasikan di jurnal ilmiah lokal maupun nasional ber-ISSN.

Selain materi yang disampaikan tentang sistematika penulisan artikel jurnal ilmiah, juga dilakukan sesi diskusi dan tanya jawab selama kegiatan pelatihan. Situasi pelaksanaan diskusi dan tanya jawab nampak hidup demikian juga waktu tutorial berjalan dengan baik. Karena para guru merasa perlu untuk mereka dalam pengusulan kenaikan pangkat dan golongan serta sertifikasi. Kegiatan seperti ini belum pernah dilakukan di Sekolah SMA Negeri 1 Palangka Raya. Sehingga para guru dan Kepala Sekolah meminta kegiatan semacam ini agar diadakan lagi. Berikut adalah daftar judul artikel yang akan ditindaklanjuti oleh guru-guru SMA Negeri 1 Palangka Raya setelah mengikuti pelatihan untuk dapat diterbitkan di jurnal Ilmiah lokal maupun nasional berISSN.

\section{Faktor Penghambat dan Pendukung \\ Faktor Penghambat:}

1. Peserta telah dipilih yang masih senior dan tidak semuanya PNS tetapi masih ada yang honorer. Sedang yang PNS masih ada yang golongan II sehingga belum merasa perlu pembuatan karya tulis ilmiah itu karena baru dipandang perlu jika sudah golongan IIIb.

\section{Faktor Pendukung:}

1. Gedung SMA Negeri 1 Palangka Raya dekat jalan raya sehingga tranportasi mendukung gedungnya cukup untuk pelaksanaan pelatihan.

2. Gedung SMA Negeri 1 terletak dikota Palangka Raya dan sangat dekat dengan Universitas Palangka Raya sebagai tempat bertugas narasumber.

3. Materi diperlukan oleh mayoritas guru untuk kenaikan pangkat dan sertifikasi.

Tabel 3. Daftar Karya Tulis IImiah Guru-Guru SMA Negeri 1 Palangka Raya

\begin{tabular}{clll}
\hline NO & NAMA PENULIS & \multicolumn{1}{c}{ JUDUL ARTIKEL } & BIDANG \\
\hline 1 & Dyah Setyorini & $\begin{array}{l}\text { Kesulitan Memahami Faktor-faktor yang } \\
\text { mempengaruhi Kesetimbangan Kimia pada Siswa SMA } \\
\text { Negeri di Kota Palangka Raya }\end{array}$ & Kimia \\
\hline 2 & Ike Valentie & $\begin{array}{l}\text { Pemahaman Konsep Hidrolisis Hasil Belajar Kimia } \\
\text { Menggunakan LKS-Induktif pada Siswa Kelas XI }\end{array}$ & Kimia \\
\hline
\end{tabular}




\begin{tabular}{|c|c|c|c|}
\hline NO & NAMA PENULIS & JUDUL ARTIKEL & BIDANG \\
\hline 3 & Yusmiati & $\begin{array}{l}\text { Konsepsi Siswa Tentang Gaya Hidup Modern pada } \\
\text { Kelas XI MIPA } 1\end{array}$ & $\begin{array}{l}\text { Pendidikan Agama } \\
\text { Kristen }\end{array}$ \\
\hline 4 & $\begin{array}{l}\text { Yusnani } \\
\text { Novelianty }\end{array}$ & $\begin{array}{l}\text { Mengembangkan Keterampilan Abad } 21 \text { melalui } \\
\text { Inovasi QR Code dalam Mata Pelajaran Sejarah di } \\
\text { SMAN } 1 \text { Palangka Raya }\end{array}$ & Sejarah \\
\hline 5 & Santa & $\begin{array}{l}\text { Menulis Teks Anekdot Siswa Kelas I IBB Pengaruh } \\
\text { Nyata dan Kajian }\end{array}$ & Bahasa Indonesia \\
\hline 6 & Budi Santoso & IBL untuk Data Digital pada Kelas XII MIPA & Fisika \\
\hline 7 & Kristanti & $\begin{array}{l}\text { Minat Siswa untuk mengenal Pahlawan-Pahlawan } \\
\text { Nasional }\end{array}$ & Sejarah Indonesia \\
\hline 8 & A. Murianti & $\begin{array}{l}\text { Peningkatan Pembelajaran Kimia Sifat Koligatif } \\
\text { Larutan Abad } 21 \text { Kelas XII MIPA } 2 \text { menggunakan } \\
\text { Aplikasi Pembelajaran Smart APP }\end{array}$ & Kimia \\
\hline 9 & Ernita F & $\begin{array}{l}\text { Pengaruh Media Audio Visual terhadap Minat Belajar } \\
\text { Siswa dalam Pendidikan Agama Katolik dan Budi } \\
\text { Pekerti di Kelas X MIPA } 2 \text { SMA Negeri } 1 \text { Palangka Raya }\end{array}$ & $\begin{array}{l}\text { Pendidikan Agama } \\
\text { Katolik dan Budi } \\
\text { Pekerti }\end{array}$ \\
\hline 10 & Karlae & $\begin{array}{l}\text { Pemahaman Konsep Virus setelah Penerapan Model } \\
\text { Pembelajaran Discovery Learning pada Siswa Kelas X } \\
\text { IPS SMA Negeri } 1 \text { Palangka Raya }\end{array}$ & Biologi \\
\hline 11 & Tri Utami & $\begin{array}{l}\text { Pemahaman Konsep Turunan Fungsi Aljabar setelah } \\
\text { Penerapan Pembelajaran dengan Pendekatan pada } \\
\text { Siswa Kelas XI MIPA }\end{array}$ & Matematika \\
\hline 12 & Sri Yanuarti & $\begin{array}{l}\text { Meningkatkan Tingkat Kemampuan Siswa Kelas X } \\
\text { MIPA SMA Negeri } 1 \text { Palangka Raya dalam } \\
\text { menyelesaikan Soal HOTS Bahasa Inggris dengan } \\
\text { Metode Discovery Learning }\end{array}$ & Bahasa Inggris \\
\hline
\end{tabular}

\section{KESIMPULAN}

Secara umum pelaksanaan pelatihan penulisan artikel jurnal ilmiah berjalan sesuai dengan yang diharapkan. Sebagian besar guru-guru yang mengikuti pelatihan penulisan artikel jurnal ilmiah merasa bahwa pelatihan ini sangat bermanfaat dan berharap artikelnya dapat dipublikasikan di jurnal ilmiah baik lokal maupun nasional.

\section{UCAPAN TERIMA KASIH}

Penulis mengucapkan terima kasih kepada pihak yang telah memberikan pendanaan kepada penulis melalui Program Hibah Pengabdian Dosen dibiayai melalui DIPA Universitas Palangka Raya Tahun 2019, sehingga pengabdian ini dapat terlaksana dengan baik.

\section{DAFTAR PUSTAKA}

Bahdin, Nur Tanjung dan Ardial. 2005. Pedoman Penulisan Karya Ilmiah (Proposal, Skripsi, dan Tesis) Dan Mempersiapkan Diri Menjadi Penulis Artikel. Jakarta : Prenada Media

Brotowidjoyo, Mukayat D. 1985. Penulisan Karangan Ilmiah. Jakarta : Akademika Presindo.
Depdiknas Dirjen Dikdasmen Direktorat Tnaga Kependidikan. 2001. Pedoman Penyusunan Karya Tulis IImiah di Bidang Pendidikan dan Angka Kredit Pengembangan Profesi Guru. Jakarta

Haryanto. 2006. Rambu-rambu dan Kiat Menulis Artikel IImiah dalam Upaya Penerbitan Berkala IImiah Terakreditasi. Disampaikan dalam Lokakarya Penerbitan Majalah Ilmiah di Jurusan Administrasi Pendidikan Fakultas Ilmu Pendidikan UNY.

Maryadi. 2001. Pengertian dan Kriteria Karya Ilmiah. Dalam Harun,dkk.(Es). Pembudayaan Penulisan Karya Ilmiah (h/m.13-14). Surakarta : Universitas Muhammadiyah Surakarta.

Peraturan Menteri Pendayagunaan Aparatur Negara dan Reformasi Birokrasi No. 16 Tahun 2009, 2009. Tentang Jabatan Fungsional Guru dan Angka Kreditnya. Yogyakarta

Republik Indonesia. Peraturan Menteri Pendidikan Nasional No. 35 Tahun 2010 tentang Petunjuk Teknis Pelaksaan Jabatan Fungsional Guru dan Angka Kreditnya, Kementerian Negara Pendayagunaan Aparatur Negara dan Reformasi Birokrasi. Jakarta. 
Soeparno. 2005. Bahasa Indonesia Untuk Penulisan Karya Tulis IImiah. Makalah Disampaikan Dalam Kegiatan Pelatihan Penulisan Bahan Kuliah (Buku Pegangan Kuliah). Jurusan AP FIP UNY, 16-20 Mei 2003.

Suyanto. 2001. Teknik Penulisan Artikel Imiah. Makalah disampaikan dalam Lokarkarya Penulisan Jurnal Penelitian Humaniora di Lembaga Penelitian Universitas Negeri Yogyakarta, 23 Oktober 2003.

Suyanto, 2007. Tantangan Profesional Guru di Era Global. Pidato Dies Natalis ke-43 UNY

Tatang, M,Amirin. 2006. Menulis Karya Ilmiah (Artikel). Makalah Pelatihan Penulisan Karya Ilmiah Bagi Guru-Guru se- Indonesia. Yogyakarta, 2-3 November.

Wibowo. 2001. Managemen Bahasa Pengorganisasian Karangan Pragmatik dalam Bahasa Indonesia untuk Mahasiswa dan Praktisi Bisnis. Jakarta : Gramedia Pustaka Utama.

Johson, Burke. "Evaluation Models." http://www.southalabama.edu/coe/bset/johnson/6 60lectures/Lect2.doc (diakses 27 April 2012)

Laporan Pelaksanaan Sertifikasi Guru Dalam Jabatan Tahun 2011 Rayon 18 Universitas Palangka Raya.

McLemore, Amy. "The CIPP Model." http://birdopassage.blog.com/2011/08/28/thecipp-model/ (diakses 27 April 2012)

Peraturan Pemerintah No. 74 tahun 2008 tentang guru.

Permendiknas No. 14 Tahun 2011, tentang Sertifikasi Guru.

Permendiknas No. 16 Tahun 2007, tentang Standar Kualifikasi Akedemik dan Kompetensi Guru.

Pratama, Dinar. "Model Evaluasi Cipp (Context, Input, Process, Product)." http://dinarpratama.wordpress.com/2010/11/20/m odel-evaluasi-cipp-context-input-processproduct/ (diakses 12 Mei 2012)

Payne, D.A. “Designing educational project and program evaluations: A practical overview based on research and experience." http:www.southalabama.edu/coe/bset/Johnson/66 Olectures/Lect2.doc. (diakses 27 April 2012)

R.J, Syahrulloh. "Pedoman Pelaksanaan Administrasi dan Supervisi Pendidikan." http//rjryahrulloh.blogspot.com/2010/10/pedoman -pelaksanaan-administrasi-dan.html. (diakses 27 April 2012)

Roswati, "Evaluasi Program/proyek (Pengertian, fungsi, jenis dan format usulan)." Jurnal Pendidikan Penabur. No 11 Tahun ke-7. 2008. http://www.bpkpenabur.or.id/files/Hal.\%206471\%2 OEvaluasi\%20program.pdf (diakses 27 April 2012)

Santoso. "Supervisi Pembelajaran untuk Pembinaan Profesionalisme"

http://santosmine.blogspot.com/2010/01/supervisipembelajaran-untuk-pembinaan. html (diakses 27 April 2012)

Suhil, Achmad. "Tujuan, Fungsi dan Manfaat Supervisi Pendidikan."

http://saidsuhilachmad.yolasite.com/resources/Prof esi_Kependidikan/Kegiatan\%206_Genap11.pdf (diakses 12 Mei 2012)

Syaukani "The Evaluation of The Echelon III Training Program At The Ministry Of Religious Affairs . Jurnal Evaluasi Pendidikan, Vol 2 No. 1 Maret 2011.

Undang - undang RI No. 20 Tahun 2003, tentang Sistem Pendidikan Nasional.

Undang - undang RI No. 14 Tahun 2005, tentang Guru dan Dosen.

Yusuf, Tayibnapis Farida. 2008. Evaluasi Program dan Instrumen Evaluasi untuk Program Pendidikan dan Penelitian. Jakarta: Rineka Cipta 